\title{
粗
}

\section{Spirituality: the new religion of our time?}

\author{
J.L. van der Walt \\ Faculty of Education Sciences \\ Potchefstroom Campus \\ North-West University \\ POTCHEFSTROOM \\ E-mail: jlvdwalt@aerosat.co.za
}

Abstract

\section{Spirituality: the new religion of our time?}

Mainstream religions and their institutions have since the 1960s been gradually bleeding to death because of their members leaving them in search of rather more inspirational experiences elsewhere. Christian educationists are concerned about this development, because it means that these churches have been losing their capacity for entering into meaningful tripartite pedagogical partnerships with family and school. A description of the problem of churches losing members is followed by a brief depiction of spirituality, something that can be experienced both within Christianity and elsewhere. The inability of mainstream churches to let their members experience true Christian spirituality compels the latter to go elsewhere in search of it. It is concluded that spirituality is no "new" religion after all as far as Christianity is concerned. It is in fact the quintessence of Christianity, but has through the ages become deeply buried in the mainstream religions and churches under thick layers of dogmatic and other superficialities.

\section{Opsomming}

\section{Spiritualiteit: die nuwe godsdiens van ons tyd?}

Hoofstroomgodsdienste en hulle inrigtings is sedert die sestigerjare aan die doodbloei as gevolg van die feit dat lidmate hulle verlaat in hulle soeke na meer inspirerende ervarings elders. Christen-opvoedkundiges is diep besorg oor hierdie verskynsel, aangesien dit tot gevolg het dat hierdie kerke die vermoë aan die verloor is om in 'n betekenisvolle opvoedingsvennootskap met die gesin en skool te tree. 'n Beskrywing van die probleem word opgevolg met 'n bondige uiteensetting van spiritualiteit - iets wat sowel binne die Christelike godsdiens as 
daarbuite ervaar kan word. Die onvermoë van die hoofstroomkerke om hulle lidmate die ware Christelike spiritualiteit te laat ervaar, dwing die lidmate om elders daarna te gaan soek. Die konklusie word getrek dat spiritualiteit eintlik geen "nuwe" godsdiens is sover dit die Christelike godsdiens aangaan nie. Dit is, om die waarheid te sê, die diepste essensie van die Christelike godsdiens, maar dit is deur die loop van die eeue in die hoofstroomkerke toegegooi onder dik lae dogmatiese en ander oppervlakkighede.

\section{Introduction, aim and method}

I would like to make four points right at the outset. Firstly, I write as an educationist who has in the past few decades been observing a disturbing tendency among Christian mainstream religions and churches. The second point is that this article does not purport to be "theological"; it does not seek to promote the interests of theology as a scholarly discipline. Its purpose is rather to bring a problem, encountered in the realm of education, to the attention of theologians and church leaders. It is in their interest as Bible scholars and church leaders to take cognisance of what I offer here, to interrogate my findings and observations, and to respond to them. Thirdly, as a non-theologian, I am not qualified for the task of theological evaluation, assessment and critique. This does not prevent me, however, as an "ordinary" practising and church-going Christian from making certain observations in passing and from offering bits of advice. Finally, the discussion will here and there be controversial and unorthodox. This comes with the territory.

The problem is as follows: the tendency among church members to leave mainstream religion behind in favour of a "new" and rather nebulous religious experience depicted as "spirituality". The formulation of the problem gave birth to the method I shall be following as well as to the structure of the article. I shall firstly interpretivistically describe, on the basis of literature, augmented by my own experiences and observations, to what extent members of Christian denominations have in the recent past turned their backs on mainstream religion and its institutions, and how they search spirituality elsewhere. I then contend that while spirituality has always been the quintessence of Christian faith it has been deeply buried in mainstream churches under layers of dogmatic and other superficialities. I conclude by suggesting a strategy for assuaging the problem. 


\section{People turning their backs on traditional, mainstream religion and churches}

The contents of this section will be nothing new to theologians and church leaders who follow social trends. Let me therefore only reiterate a few succinct facts. People are leaving the established or mainstream churches in substantial numbers. In the United States of America, for instance, church attendance is nearing 20-year lows and growth has become stagnant. According to LinkedWordsBeta (2008), mainstream denominations are struggling with the fact that weekly worship attendance has declined from 49\% in 1991 to $43 \%$ in 2008.

The Church of England has a worldwide nominal membership of approximately 25 million of whom only about 2 million are still actually enrolled and regularly attend the local parishes. The 2004 Yearbook of American and Canadian churches cites a 1991-membership figure of approximately 5,5 million members for the Church of God in Christ. Although this figure has not been updated, experts believe that the church has less than 5 million members today (Wikipedia, 2008).

The membership of the Reformed Churches in South Africa (Gereformeerde Kerke in Suid-Afrika) grew to approximately 90000 in the 1990s, and then dropped to 74952 in 2000, to 73748 in 2002, to 70225 in 2007, and now stands at 68842 in 2008 (RCSA, 2003; 2008:418) - a decline in membership of about 1000 per annum around 1990 and about 2000 per annum by 2000 .

Between 1985 and 1993, the Dutch-Reformed Church (Nederduitse Gereformeerde Kerk) in South Africa lost approximately 150000 of its members. In 1997 alone, it lost approximately 21 000. Morning sermons are attended by only about $36 \%$ of the enrolled members; evening services by only 9,5\% (Nel, 2003:18). In the Netherlands, both the Nederlandse Hervormde Kerk (NHK) and the Gereformeerde Kerken (synodaal) reported a decline in their membership, especially among young people, since as early as 1969. Approximately $38 \%$ of the adult population in the Netherlands has no religious affiliation (Vermeer \& Van der Ven, 2004:55). The same tendency can be observed in the Church of England in Britain. Its membership numbers began declining steadily from 1974 onwards (RCSA, 2000). In Europe, according to Nel (2003:18), approximately 35000 members turn their backs on the churches every week. In England alone, 1500 members leave the church every week (and this does not include the so-called church-hoppers). 
Where churches have indeed increased and grown in numbers, it is not because of the fact that they provide spiritual homes to believers, but because of the political roles that they play as bulwarks against an oppressive state apparatus and the social services they can provide (as in China where house churches and sects flourished during the Falun Gong persecutions) (cf. Goodstein, 2005).

Kuitert (2005:185), a Christian theologian with rather unorthodox views about Christian (reformed) theology, suggests that conditions in established religion and its institutions compel members to leave (cf. also Fowler, 1999; Hitchens, 2007). According to Kuitert (2005), traditional religion and worship (in casu: Christianity) has in the course of its history become a too complicated lattice work of doctrines, dogmas, cults, rites, symbols, representations, teachings, sacraments, catechisms, confessions, articles of faith and so on. This doctrinal lattice work, he argues with the aid of a set of mixed metaphors, has not only bounded in (bonded in leather as it were, as in a book) believers/church members spiritual experience; it has also "snowed under" their direct and personal experience of God. A quest for more profound (spiritual) experience has come to the surface in recent years as a form of resistance to the church's "too finely distilled" dogmatic views about God, to the tired clichés coming from pulpits and altars, to the musty clichés that cannot soar anymore but collapse like powerless birds.

Those who have given up on the mainstream churches and religion are "de weglopers" (literally: the walkers-away, deserters) (Kuitert, 2005:98). For generations now, people have been resigning from the churches because of their disappointment in the churches, their teachings and activities, especially their rigid and lifeless doctrines (Kuitert, 2005:99). Still being active believers and seekers of the truth, they tend to join groups that dabble with "new" forms of spirituality. According to some of de weglopers, they can still associate themselves with the general Christian spirit prevalent in their cultural surroundings, at least for the time being.

Their children are, however, lost to the church (Kuitert, 2005:100). A survey by the MTV television channel revealed that $99,4 \%$ of the young people interviewed outside the mainstream churches still "believed in something", though not in Christianity or any church. Spirituality was reaching a climax, but not the form of spirituality associated with the mainstream religions and denominations ( $\mathrm{Nel}$, 2003:19). This can be seen in the preference of the Dutch and Belgians for an impersonal God, not the classic concept of a per- 
sonal God associated with Christianity and the mainstream churches (Ganzevoort, 2004:116, 119). Vermeer and Van der Ven's (2004:54) empirical study revealed that while Dutch secondary school students are still inclined to believe in the existence of God or a transcendent reality, they do not consider themselves as members of a church or part of a religious community. According to Shutte (2005:291), this tendency towards the deinstitutionalisation of religion with a parallel stronger focus on the experiential dimension of religion (Ganzevoort, 2004:122), the alternative search for deeper spiritual meaning, is understandable in societies dominated by a modernistic, scientific and secular worldview.

What can be done to combat this tendency? Several strategies have been tried but seemingly did not work. The first is constant reversion to Biblical and doctrinal perspectives about the importance of church membership and the necessity of church attendance. For instance, a specialist committee of the Reformed Churches in South Africa brought several Biblical perspectives with respect to reformed ecclesiastical practice to the attention of Synod (RCSA, 2000: par. 2.3). No right-minded Bible believer and church-goer would differ with any of these perspectives; they are all valid from a Biblical point of view. And yet, reiteration of such Biblical guidelines did not work it did not stop the rot.

The second solution was offered by the unorthodox Amsterdam University theologian Kuitert (2005:210-212) mentioned above. He advised churches to combat the problem of doctrinal emptiness and meaninglessness with a stronger appeal to the emotional experience of believers. "Emotional experience" in his opinion did not refer to base emotion or feeling. His own definition of "emotional experience" was that church members should feel themselves "personally addressed". To be addressed is to be subjective in the sense of having an "inside feeling" about "something from outside". It is the experience of being touched in one's deepest mind and heart (Dutch: gemoed); it is the experience of having been overcome by a greater power from outside, by God Himself speaking the Word that produces spirit and power, an experience that we have when we feel ourselves addressed by our fellow human beings (cf. Shutte, 2005:304-306 for a similar argument). In Kuitert's opinion, people turn their backs on the mainstream churches because they do not experience this profound feeling of being addressed. What has been going on in the churches alienates them from this feeling and related emotional knowledge (Kuitert, 2005:210-212). Kuitert's solution has been bandied around for several decades now (from 1965 when he 
became Professor of Theology until 2000 when his book Concerning religion was published) but it also could not prevent the haemorrhaging of the mainstream churches. A possible reason for its failure is the horizontalism of his view, i.e. that the feeling of being addressed by God can only come from one's fellow human beings.

In the United States and elsewhere, pastors and churches have come up with yet another strategy. They are increasingly turning to modern secular marketing methods to attract the faithful. The days when churches could simply open their doors and people would flock in just because it was some place to go, are mostly gone. Increasingly, churches and ministries find that they have to not only compete with a wide world of secular temptations, but often with each other as well. They understand that prospective worshippers will no longer sit still for the spiritual "hard sell". The churches therefore attempt to provide them with options, including spiritual experiences that speak to their personal needs (LinkedWordsBeta, 2008). According to the statistics, this strategy has not yet taken effect.

\section{Pedagogical concerns}

Concerned Christian educationists take note of these developments in the mainstream religions and the churches. The churches seem not to only have lost their pedagogical influence on all those members who already left them, but they also seem to have become irrelevant as far as (school) education is concerned (Colditz, 2008:67).

Educationists' concern deepens in view of the deterioration of family life and the secularisation of the schools (i.e. independence from religion in general, and from church influence in particular).

As far as family life is concerned, "core families" (in the sense of a married father and mother, and children born in wedlock) are being replaced by other types of families. Divorce, living together, single parenting, grandparent- and sibling-parenting, the decision not to have children, a jetsetter lifestyle, professionalism, ineffective and inept parenting, the advent of electronic games and television, and disproportionate poverty (among minorities) have all led to several variations of "non-traditional" or "non-core" and even dysfunctional families. This in turn has resulted in wayward lifestyles and undisciplined behaviour. The descriptions of family life provided by the Dutch Bureau of Statistics (2003:9, 19 ff.; 2004:14) and by Wagner et al. (2005:80) are apt portrayals of the situation in most modern 
societies (cf. also Naber, 2004:16 ff.) for a slightly more nuanced and more optimistic description of the situation in the Netherlands. Despite this, she also refers to problems experienced by less developed parents (Naber, 2004:11) and the increasing importance of peer group influence. In some developing countries, the situation is exacerbated by the HIV and AIDS and tuberculosis epidemics. Family life has indeed become compromised to such an extent that it is in no position to fulfil a partner role for either church or school.

Apart from a small number of private Christian schools (only approximately $4,3 \%$ of schools in South Africa are private; cf. Colditz, 2008:3), schools worldwide have become secularised, in other words, independent from religion and church in the name of human freedom (unless one regarded "secular humanism" as a religion; cf. Shutte, 2005:291). As secularised institutions, they are in principle not able to openly and publicly enter into meaningful pedagogical relationships with (for instance) a particular church or religious denomination. Because of the increasing demands of performativity (the demand that they should be managed like businesses for profit, and for the purpose of attaining tangible results in the form of passes and distinctions; cf. for instance Huizer, 2006), schools find it difficult to enter into meaningful relationships with parents, especially if those parents themselves are uneducated or struggling to eke out a living in a dysfunctional family and social context. In South Africa approximately $90 \%$ of the public schools are dysfunctional themselves (Colditz, 2008:2-3).

Christian educationists are concerned about all these developments because singly and in combination they signal the end of the conventional tripartite alliance among school, church and family home to which Christians attach so much importance. Since the onset of Christianity, Christian parents, church leaders and school parents and staff have insisted on an alliance among themselves for the sake of the total and efficient Christian upbringing of the children concerned. Vogelaar and Bregman (1984:25) used the three-pointed daystar metaphor to explain the nature of the alliance and cooperation. In their portrayal of the alliance, the school forms the centre of the star, and the three points refer to the family, the church and the state respectively. (I did not mention the state because I am not aware of the existence of any self-confessed Christian state. See the Editorial (Anon., 2005) for a discussion of the difficulties with respect to the state/government aligning itself with a particular religion, in this case Christian faith.) As far as I am concerned, the three points of the daystar respectively refer to family, church and 
school. According to Power (2005:17), the family, the community and the local school are the "major developmental contexts". He does not mention state or church.

Cooperation and religious alliance between family, school and church is not tenable any more because of recent developments within all three of these societal relationships. Although the problem is just as serious in the contexts of the state, family life, the school and the wider community, we have to restrict our attention here to the inability of the church to ally itself to family and school. From a Christian pedagogical perspective, the bottom line of the equation is that none of the counter-measures so far taken by the churches, their leaders and the theologians to alleviate the problem of dwindling numbers seems to have worked, and this has led to impairment of the ability of the church to be an effective education partner.

What can be done, then, to counteract the problem? I would submit that the third strategy mentioned above, that has not yet taken full effect, deserves to be explored further. The rest of the article is devoted to a discussion of this strategy.

\section{A new approach centring on the notion of spirituality}

Several Christian-reformational educationists, having noticed that mainstream Christianity and the churches have lost their power to retain many of their (younger) members, investigated the problem from another angle, namely that of spirituality. They felt themselves compelled to do so in view of the fact that spirituality has been bandied around for some time now as a possible and more viable alternative to mainstream religion and church attendance. During a conference held in Gouda (The Netherlands) in January 2008, Christian educationists presented several papers that centred on spirituality as a possible new way of approaching the problem that I have outlined in the previous sections. In one of the papers, De Muynck (2008a:7), defined spirituality as follows: "It is the manner in which one - by orienting oneself on sources - relates beliefs and experiences of inspiration and/or transcendence, more or less methodically, to the actual practice of life." He followed this up with a detailed discussion in his thesis (De Muynck, 2008b:406).

De Muynck's definition provides us with four conceptual subframeworks. It firstly refers to a person's orientation to some or other source, to his/her beliefs and experiences of inspiration in connection with a source deemed to be transcendent to the existence of 
the person in question. It secondly refers to inspiration, in other words the motivation, the experience or feeling of "being driven" to achieve something. It highlights, in the third place, that spirituality involves a process of searching, usually for personal meaning. And finally, it refers to connections between all of these processes and the actual practice of life, concrete existence.

We can imagine a person on the point of leaving a mainstream Christian church conducting the following self-conversation about his/her search for spirituality within Christianity and church life:

- Who or what is the source that I am oriented to here in the context of this church or congregation? I know from my upbringing and the belief system thus far inculcated in me through all my educational experiences that it must be the triune God. But who is He? Where can I see Him? Where can I have direct experience of Him? I have to listen to all the preaching and participate in all the activities of the church to show that I am a living member of this congregation, but how does all of it help me to connect with God, to experience a direct relationship with Him? All I have is the Bible, the teachings and dogma, the articles of faith of the church, but all of this do not connect me to Him! All of these are mere lifeless words. I do not have the benefit of a spiritual relationship with the Holy Spirit of God. Or do I have to assume that when I hear my conscience or my fellow believers speaking, that it is the Spirit speaking in and to me?

- I do not feel particularly inspired by what transpires around me in this church. I have to sit and listen; I sing approved songs from a book; I have to interact with people that I only see once a week; I do not particularly like the people around me in church - although they pretend to be God-fearing and regular church-going Christians, they do not practise what they preach. All of them are only going through the same superficial motions that I am going through. I do not even feel my prayers to be particularly inspired. And even if I do, I do not think God hears them or will ever answer them.

- Who am I? What am I doing here? What is the sense of being a member of this church? What is my relationship with the triune God? Why can I not find complete fulfilment here in this church (and in this religion)? Where else can I search for more profound meaning for myself and my life? Why do all these other church members seem satisfied with what is going on here? Am I different from them? Why am I different? Or is it just that they are 
indifferent to this deeper search for meaning in their lives? Have they just been indoctrinated? Can they not think for themselves? Do they really need a minister to tell them twice on a Sunday how they should find meaning in their lives? Can they not read the Bible and other Holy Books for themselves? Will it not be better for me to leave this religion and the church and go searching elsewhere for more fulfilling experiences? Where can I find true spiritual fulfilment?

- What does all of what I am doing here in church and on a Sunday mean for my actual life tomorrow and every other day of my life? Why, if what is happening here in church is indeed so meaningful and inspirational, is my life then such a drag? Why does my faith, my belief, this religion, my participation in church activities not help me lead a more meaningful and fulfilling life? What would happen to my every day existence if I just upped and left the church? Would I not be happier in my ordinary daily existence if I tried to search for God elsewhere? Why do I have to feel sanctioned by the church and by my family for thinking differently from them? Why do I have to feel guilty?

Let us not deceive ourselves into thinking that this is an imaginary self-conversation. The controversial Christian-reformed theologian whose name I mentioned above also refers to the questions that "those outside the walls" of the churches asked themselves before they left (Kuitert, 2005:31). People who do not ask themselves such questions are not real live people (Kuitert, 2005:157). Because the mainstream churches are not able to provide meaningful answers to these deeper spiritual questions, people are turning their backs on them. As a result, says Kuitert (2005:98), "religion in the more orthodox churches is going downhill". Whether one agrees with Kuitert or not, it is important to listen to what he says about what people are actually searching for:

People are searching for a 'kick' from the 'other side' (i.e. from what is deemed to be transcendent). The 'other side' has therefore to be added to the subjective pool of a believer. The 'other side' is fundamental. One experiences religion in the realities of every day, in everyday life. That is where it comes from, that is where it should fit in, and if it does not fit there, then we are not dealing with a true religious experience and we are right back to doctrine $[. .$.$] we then failed to have an experience of the 'other$ side' [...] our subjectivity, our imagination, has to be connected to something that brought our subjectivity to the surface in the first place, that provoked it [...] we have to feel on the inside that we have been addressed by some or other power (Power). 
[...] I see in this an event, something that overcomes a person, that cannot be resisted, an undeniable experience stronger than oneself. That is why people surrender to it - because they see something worthwhile in it. [...] It is to feel yourself addressed by it; it is a feeling that impresses itself on one (Kuitert, 2005:110-111, 182, 187-188; translated from Dutch - JLvdW).

Another "ordinary" church-going Christian believer, this time a philosopher, expressed similar sentiments:

[n my opinion,] the way we believe should not amount to an uncritical echoing of the standard ecclesiastical doctrines and of the theological interpretations of those doctrines which have attained a certain authority in our culture. As far as I am concerned, to still believe unavoidably means to think anew and in some cases differently. [...] My reflections on faith are motivated by my sense, right or wrong, that we, especially in the reformed tradition, have made too much of a theoretical exercise of faith - a matter of the mind and of cerebral effort - and not sufficiently of every day practice. In contrast to this, the faith that we learned from Jesus is a way of life. This does not mean that we do not have to understand and reflect about it - of course one should have a mental grip on things. However, the faith that we learned from Jesus is just as much (if not more!) practice than theory. (Van Niekerk, 2005:34; translated from Afrikaans - JLvdW.)

Theologians and church leaders have to ask themselves whether the offerings of the orthodox Christian-reformed churches and other mainstream religions are indeed providing in these needs of each individual member. This is an important question in view of the fact that doctrinal formulations of religious faith change slightly and slowly, if at all. Religion is essentially conservative in this respect (Shutte, 2005:290).

\section{What can be done to address the situation?}

Theologians and mainstream church leaders may shake their heads and say that what has been said in the previous section just does not fit in with (in casu) conventional Christian-reformational thinking. But that would be beside the point. The mainstream churches and religious denominations have been losing touch with their members and are in the process of deteriorating into insignificant little groupings consisting of aged, orthodox- and conventional-thinking and -believing members. Those who should have contributed to the future growth of the churches - the young people - have already left 
in substantial numbers. What can be done? The following are a few pointers flowing from an understanding of spirituality, of which mainstream churches and their leadership could take cognisance if they wished their denominations and institutions to survive into the future.

Firstly, theologians, ministers and leaders of mainstream churches and religious groupings should make a mind-shift, away from thinking in terms of the standard doctrinal truths of their respective religious denominations towards thinking more in spirituality terms. Irrespective of whether we are referring to spirituality in mainstream religious and ecclesiastical context or to spirituality outside of these confines, spirituality remains the way in which a transcendent and ultimate reality impacts on people so that they become willing servants of that ultimate reality. (Outside of the mainstream churches the "new" language of spirituality refers to the sacred as "an energetic dimension of life" (Ganzevoort, 2004:120)). Spirituality can evoke a whole spectrum of aspects concerning the lives of human beings, but it remains in essence a form of passion, a sensation of being driven (motivated), the experience of having been laid claim to (Hardjono \& Klamer, 2005:21). According to Roothaan (2007:43), it is both a form of experience and a way of doing. Spirituality in her opinion tells us something about how a person conducts him-/herself in life, but it also refers to his/her attitude through which she/he shows how she/he is being moved by that which is regarded as the greatest mover (inspiration). In essence, spirituality refers to lifeattitude, the stance or habitus of the individual that maintains the balance between spiritual experience and action.

As Abdool et al. (2007:547) argued in another context, all individuals and groups tend to ask questions that come from the deep spiritual level of their humanness: Who am I, and how do I relate to the divine, to evil and unhappiness or loss, guilt and shame? Irrespective of whether associated with mainstream religion, faith and religious institutions, or whether supraconfessional and -denominational, spirituality symbolises the human being's quest for depth and values, and describes how a person or people relate their beliefs and actions towards what they regard as the divine and/or otherness with their own being and core values. In a sense, the spiritual dimension represents the mystical face of religion, the fountainhead of divinity, and the source and essence of the soul.

This typology of spirituality that we find in philosophical, religious, theological and educational circles shows that it will indeed require a change in mindset among theologians and mainstream church leaders for them and their sermons to remain relevant to parishio- 
ners of the 21st century. What this in effect means is that theologians, ministers and church leaders should pay more attention to the project of making the triune God more spiritually rather than doctrinally or dogmatically relevant to believers. Sermons and other experiences should connect church members with the Divine, should bring them personally and increasingly in tune with the Divine. It should provide them with a "peak experience" (Maslow's term for engaging with something larger than the self) of "ultimacy or ultimate concern" (Tillich's terms), make them experience the exaltation of living coram Deo. Shutte $(2005: 289,290)$ speaks of "the fulfillment of our most fundamental natural desires, especially those that seem beyond all human power to fulfill", "a comprehensive personal attitude, including volitional and emotional as well as cognitive elements". The efforts of their church leaders should bring people in closer contact with the triune God, among others by helping them make more intimate contact with Jesus Christ as the living Word of God (with - some would argue - less emphasis on the Old Testament/Jewish sacrificial substructure of His death). Their interactions with their congregations should assist church members to connect more intimately with the workings of the Spirit of God. In layman's terms, more intimate acquaintance and encounters with the living and teaching Christ and with the immanence of the Spirit should serve to spiritually draw open the curtains of the window on God, so that believers can attain more intimate knowledge of Him in all his majesty. These encounters should serve to spiritually open up the hearts of the believers, so that He can through his Spirit move (inspire) them towards continual service and worship in his honour, and to bear the fruits of the Spirit (Gal. 5:22 ff.).

Granted, all of this might not be typical, conventional, orthodox Christian-reformed theology. But this is precisely the point: theology, doctrine, dogma - those theoretical exercises of faith - should be tuned down in favour of a more deliberate search for that spirituality that is the quintessence of Christianity: experience of the source of inspiration, God; accompaniment in the search for ultimate meaning; the search for personal and existential meaning in the presence of the triune God; application of spiritual meaning in every day life. Orthodox Christian-reformed theologians might add that the search for spiritual meaning will remain meaning- and directionless unless it is rooted in dogmatic foundations (e.g. Dutch Confession, Section 24, Heidelberg Catechism Q. and A. 55, 70; Dordrecht Doctrine, Chapter 3-4, Sections 11 and 12). The jury is still out on whether believers today are still prepared to have their spiritual experiences determined in this way. 
A mind-shift towards a greater awareness of spiritual experience and search among believers is unavoidable to keep the mainstream churches from haemorrhaging to death. (Who can say what would have happened if reformers such as Luther and Calvin had not made the mind-shift required from them in their time?)

Secondly, prospective ministers/pastors/preachers/church leaders should be purposely taught about spirituality and its ramifications. This will be a demanding task (see the detailed studies by Waaijman, 2000; De Muynck, 2008b; Valenkamp \& Van der Walt, 2008, and the literature mentioned by Abdool et al., 2007). It should be brought to their attention that a rather large library of publications about spirituality is already in existence, and that the mainstream churches should be aware of its contents. They have to understand that spirituality is a rather nebulous term, but that it has nevertheless already gained such currency that the mainstream churches have lost ground because of not attending to it.

The third point of advice to the mainstream churches (including their more orthodox members) is to listen rather more carefully to the voices of those asking the difficult questions about their spirituality and its sources, as well as to those church members who come up with unconventional answers to existential problems. They should not be ridiculed, pushed away or condemned on the grounds of for instance Matthew 18:17 or Galatians 1:8-9. The established churches have to deal with an attitudinal problem among both their leaders and their members. Instead of like blinkered grain-thrashing horses forever walking in virtual doctrinal/dogmatic circles, theologians, ministers, officials as well as ordinary church members should open up themselves and their minds to the deviating opinions of their fellow church members, and also reflect more critically on the formulations of the religious faith they have inherited (Shutte, 2005:290). If, after doing so, one finds that he/she can indeed not agree with another member's rather unorthodox and even deviant opinions, she/he should continue the conversation until some closure is reached. The ground rule of the Kingdom of Christ (Matt. 22:36 ff.; 5:43 ff.; 7:12) requires us to do so. To be "conventional" and "orthodox" for the sake of conventionality and orthodoxy is no virtue in itself. A church does not survive on untested conservatism. Those searching for spirituality within Christianity is involved in an authentic search for something that the churches and their officials have been burying under deep layers of superficialities in the form of doctrines, dogmas, cults, rites, symbols, representations, teachings, sacraments, catechisms, confessions and articles of faith. 
The fourth piece of advice to ministers and church officials is more of a pastoral nature. It happens from time to time that church members come up with awkward and unconventional questions and existential problems in connection with their search for spirituality. In some cases, they approach their ministers or other church leaders to help them find a way out. The advice to pastors in the times in which we live is not to summarily revert to the doctrinal truths (the articles of faith) of the church to show that all the answers to our problems can be found there in pre-packaged form. That is not what church members want to hear. Pastors have to keep in mind that the parishioner is searching for spiritual truth, and that - as we have seen - is a commodity that is not readily available in the mainstream churches. Instead of reaching for the doctrines and the articles of faith of the church, a pastor should listen carefully to the particular believer. In most cases, such a "searching Thomas" merely wishes to have a compassionate ear.

The fifth point pertains to broader church meetings such as synods. "Ordinary" church members are beginning to view these meetings as talk-shops with no true spiritual impact. A perusal of the agendas shows that only rarely do they reflect problems pertaining to the spiritual experience of church members. Most of the topics on the agendas are of a doctrinal or mundane nature, such as whether Holy Communion may be conducted with only six big chalices or 600 small ones, whether women may serve as deacons, elders and ministers (even after having upheld the fundamental equality of both sexes), the extent to which apartheid can be justified or not, whether a new confession should be accepted or not, whether a new version of the songbook should be used, whether gay people may preach, the extent to which ownership of church property or political differences (should) prevent churches from uniting, whether state education conforms to Christian dogma, to mention only a few of the rather dull topics that synods and other church meetings have been occupying themselves with. Church meetings should rather be about the spiritual needs and requirements of members. While many of the topics may be important in terms of running a church as an organisation, those discussing the topics in the meetings should be mindful of the fact that whatever is said or done should be in the interests of addressing the spiritual needs of "ordinary" church members/believers. Dogmatic, doctrinal and many organisational considerations should be removed to the periphery in the interest of providing in the spiritual needs of all those members not present. 
The sixth point deals with the relationship between the church, the school and family life. Ministers and other church leaders have to understand that in today's world there is no chance any more of close fundamental cooperation between these three societal relationships - at least not in the conventional sense. Church leaders should nevertheless reach out to those involved in the other two societal relationships. As far as I can see, the future of Christianity, including of Christian education, cannot be made dependant any more on the Christian ethos, identity or culture of either family life, the state or schools as societal institutions. The prolonged existence of Christianity/the churches depends on the faith and the loyalty to the Kingdom of God of individual Christians - wherever they may find themselves. Churches have to reach out to such persons wherever they are - including those who have already left the church but still retain a modicum of Christianity. If they are not found and returned to the fold of Christianity, they as well as their descendants will be lost to the cause of the Kingdom.

Finally, Christian educationists and church leaders should avail themselves of the "new" emphasis on spirituality to promote the ideals of multi-, cross- and interreligious education. As has emerged in the discussion above, all people experience some or other form of spirituality (with its four aspects: orientation to a source, inspiration, the search for personal meaning, and its application in every day life). Educators, in whatever context (school, church, family home, penal institutions) should help the educand (the person being educated) understand his/her own spiritual status (their responses to the four aspects). Once a group of people (such as a school class group, a culturally diverse congregation) understand that they all share some or other form of spirituality, they will develop greater mutual understanding. This strategy can be applied in mainstream churches having to cope with increasing diversity (gender, age, socio-economic background, language, origins, ethnicity, race, to mention only a few of the variables associated with multiculturalism). This will enable members to, in due course, venture into understanding the differences associated with their respective particular forms of spirituality. With multi-ethnicity, multiculturalism and multireligiosity (different forms of spirituality commensurate with religious differences) increasing all over the world (Power, 2005:13), this will become the most suitable strategy to nurture mutual understanding and tolerance. 


\section{Concluding remark}

Spirituality is, as we have seen, not really the "new" religion of our time. What is new is the fact that people are more enthusiastically searching for spiritual meaning. If they do not find it in mainstream religion or churches, they search for it elsewhere, and develop a new-speak for referring to matters spiritual. The answer to this conundrum is for the mainstream churches to realise that spirituality is the quintessence of the Christian faith, but that it has through the centuries been buried under thick layers of superficialities, not the least of which is a surfeit of doctrines and dogmas.

The fact that people are turning their backs on the mainstream churches should serve as a wake up call for the churches: it can not any longer be business as usual for them. They face a simple choice. Either continue with the current religious teachings and practices and haemorrhage to death through the constant loss of members searching for deeper spiritual meaning in their lives, or adopt a somewhat different approach that would bring members in touch with the quintessential spirituality of the Christian faith. Although this advice might sound somewhat radical and controversial, it can be Biblically substantiated (cf. Van der Walt, 1986; 1990; De Villiers, 2007). Theologians and church leaders should now take up the gauntlet.

\section{List of references}

ABDOOL, A., POTGIETER, F.J., VAN DER WALT, J.L. \& WOLHUTER, C.C. 2007. Inter-religious dialogue in schools: a pedagogical and civic unavoidability. Hervormde theologiese studies, 63(3):543-560.

ANON. 2005. Editorial: the Monitor's view limits of religion in public life. Christian science monitor, 97(150):8.

COLDITZ, P. 2008. Perspektief op die werklikhede van skoolonderwys in SuidAfrika. Paper read at a meeting of the Management of the NK Church, Benoni, 20 August.

DE MUYNCK, B. 2008a. Summary of the dissertation "A Godly vocation". Paper read at the Conference on Spirituality and Education, 14 January. Gouda: De Driestar-educatief.

DE MUYNCK, B. 2008b. Een Goddelijk beroep. Herenveen: Groen.

DE VILLIERS, J. 2007. Die NG Kerk word stil. Insig: 22-25, Jan.-Feb.

DUTCH BUREAU OF STATISTICS. 2003. Jeugd 2003: cijfers en feiten. Voorburg: Heerlen.

DUTCH BUREAU OF STATISTICS. 2004. De Nederlandse samenleving 2004: sociale trends. Voorburg: Heerlen.

FOWLER, J.A. 1999. God hates religion. http://www.scribd.com.docs. Date of access: 4 Jan. 2009.

GANZEVOORT, R.R. 2004. Receptivity and the nature of religion. Journal of empirical theology, 17(1):115-125. 
GOODSTEIN, L. 2005. From mosque to steeple, faith rises. The New York times (articles selected for Sunday times): 1, 4, 23 Jan.

HARDJONO, T. \& KLAMER, H. 2005. Breng spirit in je werk! Zoetermeer: Meinema.

HITCHENS, C. 2007. Religion poisons everything. Sunday times: 29, 20 May.

HUIZER, H. 2006. Kinderen: wat zijn dat? Wat is de hoofdfocus van jouw organisatie?. Dordrecht: Vereniging Een School met de Bijbel.

KUITERT, H.M. 2005. Over religie. Baarn: Ten Have.

LINKEDWORDSBETA. 2008. http://linkedwords.com/society/religion-andspirituality/church/church_attendance.php Date of access: 25 Sept. 2008.

NABER, P. 2004. Vriendschap en sociale cohesie: de rol van leeftijdgenoten in de opvoeding van jeugd. Inaugural lecture on occasion of accepting the post of lecturer "Leefwerelden van Jeugd", 17 March. The Hague: Hogeschool INHOLLAND.

NEL, A. 2003. Op soek na God ... buite die kerk? Wellington: Lux Verbi.BM.

POWER, C. 2005. Quo Vadis? Education for what purpose? Social alternatives 24(4):13-17.

RCSA

see Reformed Churches in South Africa

REFORMED CHURCHES IN SOUTH AFRICA. 2000. Report by the deputies for the Preservation and Growth of the Church (Sections 88, 242). http://www.gksa.org.za/ Date of access: 25 Sept. 2008.

REFORMED CHURCHES IN SOUTH AFRICA. 2003. Report on the management of the Administrative Bureau with respect to financial planning by the Reformed Churches (Sections 94, 95, 235). http://www.gksa.org.za/ Date of access: 25 Sept. 2008.

REFORMED CHURCHES IN SOUTH AFRICA. 2008. Almanac. Potchefstroom: Administrative Bureau.

ROOTHAAN, A. 2007. Spiritualiteit begrijpen. Amsterdam: Boom.

SHUTTE, A. 2005. The possibility of religion in a scientific and secular culture. South African journal of philosophy, 24(4):289-307.

VALENKAMP, M. \& VAN DER WALT, J.L. 2008. The spiritual dimension of quality of life, with special reference to education and spirituality. (In Møller, V. \& Huschka, D., eds. Quality of life and the millennium challenge. Dordrecht: Springer Science \& Business Media B.V. p. 81-97.)

VAN DER WALT, J.J. 1986. Teen hierdie strominge in die kerk. (In Van der Walt, B.J. Onderskeiding van die geeste. Potchefstroom: IRS. p.126-139.)

VAN DER WALT, J.J. 1990. Ken en vertrou: St. 9. Potchefstroom: Administratiewe Buro.

VAN NIEKERK, A.A. 2005. Geloof sonder sekerhede. Wellington: Lux Verbi.BM.

VERMEER, P. \& VAN DER VEN, J.A. 2004. Looking at the relationship between religions: an empirical study among secondary school students. Journal of empirical theology, 17(1):36-59.

VOGELAAR, D. \& BREGMAN, C. 1984. School, maatschappij en cultuur in Bijbels licht. Hendrik Ido Ambacht: Begeleidingscentrum Gereformeerd Schoolonderwijs.

WAAIJMAN, K. 2000. Spiritualiteit. Gent: Carmelitana. 
WAGNER, M., KUTASH, K., DUCHNOWSKI, A.J., EPSTEIN, M.H. \& SUMI, W.C. 2005. The children and youth we serve: a national picture of the characteristics of students with emotional disturbances receiving special education. Journal of emotional and behavioral disorders, 13(2):79-96.

WIKIPEDIA. 2008. Church membership, church attendance. http://en. wikipedia.org/wiki/List_of_the_largest_Protestant_churches_of_the_world Date of access: 25 Sept. 2008.

\section{Key concepts:}

Christianity

church

education

family

religion

school

spirituality

\section{Kernbegrippe:}

Christendom

gesin

godsdiens

kerk

opvoeding

skool

spiritualiteit 
